\title{
PENERAPAN MODEL PEMBELAJARAN INQUIRY BASED LEARNING UNTUK MENINGKATKAN KETERAMPILAN PEMECAHAN MASALAH FISIKA PESERTA DIDIK
}

\author{
Karmila $^{1, a}$, Hardi Hamzah ${ }^{2, b}$, dan Mutmainna ${ }^{3, c}$ \\ ${ }^{12} 3$ Universitas Sulawesi Barat.

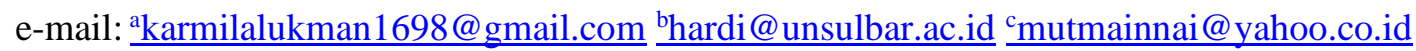

\begin{abstract}
Abstrak
Penelitian ini bertujuan untuk mengetahui perbedaan yang signifikan keterampilan pemecahan masalah fisika peserta didik setelah menerapkan model pembelajaran Inquiry Based Learning. Metode yang digunakan dalam penelitian ini adalah pre-experimental dengan desain one-group pretest- posttest. Populasi dalam penelitian ini adalah seluruh peserta didik kelas XI MIA MAN 1 Majene yang berjumlah 33 orang peserta didik. Sampel yang diteliti sebanyak 29 orang yang dipilih dengan teknik sampling jenuh. Instrumen pengumpulan data berbentuk tes uraian. Data dianalisis dengan menggunakan analisis deskriptif dan inferensial. Penelitian menunjukkan bahwa keterampilan pemecahan masalah fisika peserta didik sebelum diterapkan perlakuan berada pada kategori cukup baik (rata-rata 9,36) dan setelah diterapkan perlakuan berada pada kategori baik (rata-rata 17,34). Kemudian nilai N-gain dari hasil pretest dan posttest keterampilan pemecahan masalah sebesar 0,51 (sedang).
\end{abstract}

Kata kunci: inquiry based learning, keterampilan pemecahan masalah.

\section{IMPLEMENTING INQUIRY BASED LEARNING TO IMPROVE STUDENT'S PHYSICS PROBLEM SOLVING SKILLS}

\begin{abstract}
This study was aimed to find out a significant differences in student's physics problem solving skills after the implementation of Inquiry Based Learning. The research was pre-experimental with one-group pretest-posttest design. The population were 33 student's of eleventh grade of MIA MAN 1 Majene. The sample was 29 student's chosen by saturated sampling technique. Data was collected with essay test. The. The Data analysis was administered with descriptive and inferential technique. The result of research that student's physics problem solving skills were quite good (mean of 9,36) and good category (mean of 17,34) after the treatment. Ultimately, student's physics problem solving skills were improved significantly proved by $\mathrm{N}$-gain score of 0,51 (moderate).
\end{abstract}

Keywords: inquiry based learning, problem solving skills.

\section{PENDAHULUAN}

Pendidikan merupakan suatu kegiatan belajar yang dapat mengembangkan potensi diri untuk menjadi hal yang lebih baik dalam keagamaan, kepribadian, kecerdasan, serta keterampilan yang berguna pada pribadi dan masyarakat. Pendidikan dapat memberikan perubahan tetapi ini akan terjadi jika didukung oleh pengetahuan dan pemahaman sehingga menghasilkan pengetahuan baru. Hendaknya memperoleh pengetahuan baru dapat dilihat melalui pembelajaran. Dengan demikian pendidikan akan berhasil ketika mengalami proses pembelajaran yang baik. Pembelajaran adalah proses interaksi antara peserta didik dengan guru sehingga menghasilkan informasi yang dapat membangun sikap, kemampuan dan pengetahuan peserta didik.

Pada dasarnya dalam proses pembelajaran guru berperan penting adanya interaksi terhadap peserta didik. Interaksi tersebut, dapat berupa keaktifan, diskusi, sehingga tercipta proses pembelajaran yang baik [1]. Keaktifan peserta didik dalam kegiatan belajar tidak lain adalah untuk mengkonstruksi 
pengetahuan sendiri. Peserta didik aktif membangun pemahaman atas permasalahan yang dihadapi selama pembelajaran. Namun, proses pembelajaran yang terjadi di sekolah hanya berpusat pada guru yang berperan aktif dalam menjelaskan materi-materi pelajaran dan menemukan sendiri solusi dari suatu masalah [2].

Sesuai pernyataan diatas juga terjadi di MAN 1 Majene. Peserta didik hanya sebagian mampu memecahkan soal-soal yang telah dijelaskan sedangkan peserta didik yang memiliki kemampuan rendah terhadap materi akan merasa kesulitan. Pembelajaran yang diterapkan pada peserta didik masih menggunakan metode konvensional berupa ceramah dimana semua aktivitas berpusat pada guru [1]. Berdasarkan hasil pengamatan yang dilakukan terlihat saat melakukan eksperimen pada mata pelajaran fisika umumnya cenderung guru yang lebih aktif. Kebiasaan yang terjadi pada peserta didik sebagian merasa tidak memiliki kemampuan untuk memecahkan masalah melalui praktikum. Hal ini menunjukkan bahwa keterampilan untuk memecahkan masalah kurang baik [3]. Kurangnya kemampuan peserta didik dalam memecahkan masalah terlihat ketika peserta didik melakukan praktikum bergantung dari guru yang membimbing. Guru masih mendominasi kegiatan praktikum sehingga peserta didik kurang terlatih dalam memecahkan masalah. Hal ini menyebabkan keterampilan peserta didik rendah sehingga keinginan peserta didik untuk menemukan sendiri menurun. Selanjutnya juga terlihat ketika peserta didik dihadapkan pada soal penerapan rumus peserta didik masih mampu menjawab, namun ketika peserta didik dihadapkan dengan soal fisika pemecahan masalah yang perlu menggunakan analisis, peserta didik tidak mempunyai ide untuk menyelesaikannya [4].

Kemampuan guru dalam memilih metode penyajian materi merupakan hal penting dalam kegiatan belajar mengajar. Diperlukan suatu model pembelajaran yang dapat mengaktifkan peserta didik yang dapat menumbuh kembangkan keterampilan pemecahan masalah fisika yaitu dengan menerapkan model pembelajaran Inquiry Based Learning. Model ini merupakan model pembelajaran yang berpusat pada peserta didik. Inquiry dapat diartikan sebagai penyelidikan dan meminta keterangan informasi [5]. Bagian paling penting dari model pembelajaran ini adalah peserta didik diberikan kesempatan untuk menyusun pertanyaan, mengumpulkan ide-ide melalui observasi, dan mengumpulkan data atau informasi [6]. Model pembelajaran inquiry didefinisikan sebagai suatu rangkaian kegiatan belajar yang melibatkan secara maksimal seluruh kemampuan peserta didik untuk mencari dan menyelidiki masalah secara sistematis, kritis, logis, dan analisis sehingga peserta didik dapat merumuskan sendiri penemuannya dengan rasa percaya diri [7]. Pembelajaran IBL (Inquiry Based Learning) merupakan pembelajaran konstruktivisme yang melibatkan peserta didik secara aktif di dalam pembelajaran, memberikan kesempatan kepada peserta didik untuk mengumpulkan dan menganalisis informasi, mengeksplorasi pemikiran dan penalarannya sehingga peserta didik memperoleh pemahaman yang mendalam mengenai materi pembelajaran yang sedang dipelajari [8]. Model pembelajaran Inquiry Based Learning merupakan model pembelajaran yang memiliki tujuh komponen utama yaitu,konstruktivisme, penyelidikan, bertanya, masyarakat belajar, pemodelan, refleksi, dan penilaian sebenarnya [9] Pembelajaran inquiry adalah suatu strategi yang membutuhkan peserta didik menemukan sesuatu dan mengetahui bagaimana cara memecahkan masalah dalam suatu penelitian ilmiah, dengan tujuan untuk mengembangkan sikap dan keterampilan peserta didik yang memungkinkan menjadi pemecah masalah yang mandiri [10]. Model pembelajaran inquiry menjadi tiga jenis yaitu inkuiri terbimbing;, inkuiri bebas, inkuiri yang dimodifikasi [11]. Dalam penelitian ini, peneliti menggunakan model pembelajaran inkuiri terbimbing. Karena penerapan model pembelajaran inkuiri terbimbing ini dilaksanakan pada peserta didik dimana peserta didik masih memerlukan bimbingan dalam proses pembelajaran Ada beberapa manfaat yang bisa diperoleh dari pembelajaran inquiri [12]. Pertama peserta didik akan mempunyai kemampuan memecahkan masalah secara kreatif. Kedua, pada saat peserta didik menemukan konsep pada pembelajaran inquiry akan mengurangi perasaan tegang dan membuat proses 
pembelajaran menjadi menyenangkan sehingga respon dari peserta didik menjadi baik.

Secara umum langkah-langkah model Inquiry Based Learning sebagai berikut (1) Orientasi, (2) Merumuskan Masalah, (3) Merumuskan Hipotesis, (4) mengumpulkan data, (5) menguji hipotesis, (6) merumuskan kesimpulan [13]. Penerapan model pembelajaran inquiry dapat dikatakan pembelajaran yang efektif untuk meningkatkan kemampuan pemecahan masalah fisika [12]. Hal ini didukung oleh penelitian Nupita menunjukkan bahwa penerapan model pembelajaran penemuan terbimbing dapat meningkatkan keterampilan pemecahan masalah peserta didik [14]. Penelitian selanjutnya menyatakan bahwa penerapan metode inkuiri dapat meningkatkan keterampilan memecahkan masalah [15]. Penelitian selanjutnya menyatakan bahwa penerapan Inquiry dapat menghasilkan kemampuan pemecahan masalah peserta didik [16]. Penelitian selanjutnya mengatakan bahwa pembelajaran inquiry dapat meningkatkan hasil belajar peserta didik [17]. Sehingga dapat disimpulkan bahwa model pembelajaran Inquiry dapat menghasilkan keaktifan belajar dengan meningkatkan keterampilan pemecahan masalah fisika.

Permasalahan dalam penelitian ini adalah seberapa besar keterampilan pemecahan masalah fisika peserta didik sebelum dan setelah diterapkan model pembelajaran Inquiry Based Learning dan Apakah terdapat peningkatan yang signifikan keterampilan pemecahan masalah fisika peserta didik sebelum dan setelah diterapkan model pembelajaran Inquiry Based Learning.

Tujuan penelitian adalah untuk mengetahui seberapa besar keterampilan pemecahan masalah fisika peserta didik sebelum dan setelah diterapkan model pembelajaran Inquiry Based Learning dan untuk mengetahui apakah terdapat peningkatan yang signifikan keterampilan pemecahan masalah fisika peserta didik sebelum dan setelah diterapkan model pembelajaran Inquiry Based Learning.

Manfaat dari penelitian ini adalah dapat menjadi sumbang saran serta kontribusi positif dalam rangka mengembangkan pembelajaran dan meningkatkan mutu pendidikan di sekolah khususnya pada pelajaran fisika.

\section{METODE}

Jenis penelitian ini adalah penelitian preexperimental dengan desain one group Pretest Posttest design yang dapat digambarkan sebagai berikut [18] :

\section{$\begin{array}{lll}\mathbf{O}_{1} & \mathrm{X} & \mathrm{O}_{2}\end{array}$}

Penelitian ini dilaksanakan di MAN 1 Majene, pada semester genap tahun ajaran 2018/2019. Populasi dan sampel dalam penelitian ini adalah seluruh peserta didik kelas XI MIA MAN 1 Majene yang terdiri dari satu kelas. Teknik pengambilan sampel yang dilakukan berupa teknik sampling jenuh karena semua anggota populasi digunakan sebagai sampel.

Tahap-tahap pelaksanaan dalam penelitian ini adalah pertama tahap persiapan. Pada tahap ini peneliti melakukan observasi ke sekolah, menentukan sampel penelitian, menyusun instrumen bahan penelitian, menyusun kisi-kisi instrumen penelitian, validasi butir soal ke validator ahli, dan menyusun Rencana Pelaksanaan Pembelajaran (RPP). Kedua tahap pelaksanaan. Tahap ini dilaksanakan dengan pemberian tes awal (pretest) untuk keterampilan pemecahan masalah fisika kemudian melaksanakan pembelajaran dengan menerapkan model pembelajaran Inquiry Based Learning (IBL) setelah itu melakukan tes akhir (posttest). Ketiga tahap akhir yaitu mengolah data sesuai teknik analisis yang digunakan. kemudian membuat kesimpulan.

Data yang diperoleh dalam penelitian ini berupa data keterampilan pemecahan masalah fisika peserta didik. Data hasil keterampilan pemecahan masalah fisika peserta didik diperoleh dari hasil tes pretest dan posttest. Adapun instrumen tes keterampilan pemecahan masalah dalam bentuk essay yang sudah divalidasi.

Data dianalisis dengan menggunakan teknik analisis deskriptif dan inferensial. Data yang dideskripsikan dalam penelitian ini diperoleh dari tes keterampilan pemecahan masalah fisika sebagai instrumen penelitian yang diberikan kepada kelas eksperimen berupa pretest dan posttest.

Data yang telah diperoleh dihitung nilai rata-rata dengan menggunakan rumus [19]. 


$$
\bar{X}=\frac{\sum f_{i} X_{i}}{f_{i}}
$$

Kemudian dihitung dengan mencari nilai standar deviasi melalui persamaan berikut [20].

$$
S=\sqrt{\frac{\sum\left(X_{i}-\bar{X}\right)^{2}}{n-1}}
$$

Selanjutnya untuk mengetahui nilai yang diperoleh peserta didik, maka skor diubah ke nilai dengan menggunakan persamaan sebagai berikut [21].

$$
\text { Nilai }=\frac{\text { skor mentah }}{\text { skor maksimum ideal }} \times 100
$$

Kemudian diinterpretasi kedalam kriteria-kriteria yang telah ditetapkan dan ditentukan persentasenya.

Adapun kriteria penilaian tingkat keterampilan pemecahan masalah fisika peserta didik adalah sebagai berikut [22]

Tabel 1. Kategori Penilaian Keterampilan Pemecahan Masalah

\begin{tabular}{cc}
\hline $\begin{array}{c}\text { Interval nilai } \\
\text { (Persentase) }\end{array}$ & Kategori \\
\hline $76 \%-100 \%$ & Sangat baik \\
$51 \%-75 \%$ & Baik \\
$26 \%-50 \%$ & Cukup baik \\
$0 \%-25 \%$ & Kurang baik
\end{tabular}

Selanjutnya analisis inferensial digunakan untuk membuktikan hipotesis penelitian dengan menggunakan uji-t. Sebelum dilakukan pengujian, terlebih dahulu dilakukan pengujian dasar-dasar analisis yaitu uji normalitas.

Uji normalitas yang digunakan adalah uji chi kuadrat. Kriteria pengujian pada taraf signifikan $\alpha=0,05$ dengan persamaan seperti berikut [19].

$$
\chi^{2}=\sum \frac{\left(O_{i}-E_{i}\right)^{2}}{E_{i}}
$$

Peningkatan keterampilan pemecahan masalah fisika peserta didik dianalisis dengan menghitung N-Gain menggunakan rumus [23].

$$
g=\frac{s_{\text {post }}-s_{\text {pre }}}{s_{\text {maks }}-s_{\text {pre }}}
$$

Tabel 2. Kategori Tingkat N-Gain

\begin{tabular}{cc}
\hline Batasan & Kategori \\
\hline $\mathbf{g}>\mathbf{0 , 7}$ & Tinggi \\
$\mathbf{0 , 3} \leq \mathbf{g} \leq \mathbf{0 , 7}$ & Sedang \\
$\mathbf{g}<\mathbf{0 , 3}$ & Rendah \\
\hline
\end{tabular}

\section{HASIL DAN DISKUSI}

Berdasarkan hasil analisis diperoleh data keterampilan pemecahan masalah fisika sebagai berikut:

Tabel 3. Keterampilan Pemecahan Masalah Fisika Peserta Didik

\begin{tabular}{ccc}
\hline Statistik & Pretest & Posttest \\
\hline $\begin{array}{c}\text { Skor } \\
\text { tertinggi } \\
\text { Skor }\end{array}$ & 15 & 24 \\
terendah & 5 & 9 \\
Rata-rata & 9,36 & 17,34 \\
\hline
\end{tabular}

Berdasarkan hasil analisis deskriptif pada tabel 3 menunjukkan bahwa terdapat peningkatan skor rata-rata keterampilan pemecahan masalah fisika peserta didik sebelum perlakuan dengan sesudah perlakuan. Peningkatan yang terjadi sebesar 7,98.

Adapun hasil keterampilan pemecahan

\begin{tabular}{|c|c|c|c|c|}
\hline \multirow{2}{*}{$\begin{array}{lr}\text { Indikator } & \text { keterampilan } \\
\text { pemecahan } & \text { masalah } \\
\text { Fisika } & \end{array}$} & \multicolumn{4}{|c|}{ Skor Rata-rata } \\
\hline & Pretest & Kategori & Posttest & Kategori \\
\hline Merumuskan masalah & 2,75 & Baik & 3,82 & Sangat baik \\
\hline Menganalisis masalah & 2,24 & Cukup baik & 4,2 & Sangat baik \\
\hline Merumuskan hipotesis & 0,93 & Kurang baik & 3,41 & Baik \\
\hline $\begin{array}{l}\text { Menguji } \quad \text { hipotesis } \\
\text { (melakukan eksperimen) }\end{array}$ & 2,37 & Cukup baik & 4,17 & Sangat baik \\
\hline Membuat kesimpulan & 1,06 & Kurang baik & 1,68 & Cukup baik \\
\hline
\end{tabular}
masalah fisika peserta didik berupa skor ratarata tiap indikator disajikan sebagai berikut:

Tabel 4. Hasil pretest dan posttest ditinjau dari indikator keterampilan pemecahan masalah fisika peserta didik

Berdasarkan tabel 4 menunjukkan bahwa pencapaian keterampilan pemecahan masalah fisika peserta didik tiap indikator pada pretest lebih rendah daripada skor rata-rata posttest. 
Perbandingan hasil pretest dan posttest menunjukkan bahwa keterampilan pemecahan masalah yang dicapai peserta didik lebih baik setelah menggunakan model inquiry based learning. Selama proses pembelajaran berlangsung peserta didik dilibatkan untuk menemukan masalah melalui pengamatan langsung dalam praktikum sehingga materi yang diperoleh akan mudah dipahami dan dapat bertahan lebih lama karena peserta didik ikut terlibat dalam memecahkan masalah.

Dari hasil analisis inferensial, uji normalitas data pretest diperoleh $x^{2}$ hitung $=$ $3,75<x^{2}$ tabel $=11,07$ dan posttest diperoleh $x^{2}$ hitung $=4,27<x^{2}$ tabel $=11,07$. Terlihat bahwa pada pretest dan posttest, $x^{2}$ hitung lebih kecil dari $x^{2}$ tabel, artinya bahwa data pada pretest dan posttest, tersebut terdistribusi normal.

Dari hasil analisis terdapat peningkatan yang signifikan keterampilan pemecahan masalah fisika sebelum dan setelah diterapkan model pembelajaran Inquiry Based Learning. Hasil perhitungan Gain sebesar 0,51 berada pada kategori sedang dengan syarat G-sedang = $0,30<0,51<0,70$.

\section{SIMPULAN DAN SARAN Simpulan}

Berdasarkan hasil analisis, disimpulkan bahwa keterampilan pemecahan masalah fisika peserta didik sebelum diterapkan Model pembelajaran Inquiry Based Learning dengan rata-rata 9,36 berada pada kategori cukup baik, keterampilan pemecahan masalah fisika peserta didik setelah diterapkan Model pembelajaran Inquiry Based Learning dengan rata-rata 17,34 berada pada kategori baik, dan terdapat peningkatan yang signifikan antara keterampilan pemecahan masalah fisika peserta didik sebelum dan setelah diterapkan model pembelajaran Inquiry Based Learning.

\section{Saran}

Beberapa saran yang dapat diberikan peneliti sebagai berikut: (1) Hasil dari penelitian ini dapat dijadikan sebagai salah satu bahan pertimbangan agar siswa dapat lebih aktif dalam belajar fisika dan dapat meningkatkan keterampilan eksperimennya. (2) Untuk penelitian yang serupa, kiranya dapat mengambil sampel yang lebih besar dan mempertimbangkan pokok-pokok materi yang lebih relevan agar diperoleh hasil yang lebih baik lagi.

\section{DAFTAR PUSTAKA}

[1] Arifin, M., 2011, Pengaruh Penggunaan Model Kooperatif Tipe Tari Bambu (Bamboo Dancing) Pada Standar Kompetensi Menggunakan Hasil Pengukuran Listrik Terhadap Hsil Belajar Siswa Kelas $X$ Titil SMK Negeri 2 Surabaya, Jurnal UNESA.

[2] Astuti, Y., dkk, 2013, Pengembangan Lembar Kerja Siswa (LKS) Berbasis Pendekatan Inkuiri Terbimbing Dalam Pembelajaran Kooperatif pada Materi Kalor, jurnal pendidikan IPA Indonesia, PII 2 (1) (2013) 88-92

[3] Damopolii, Insar, Pengaruh Strategi Pembelajaran Inkuiri Bebas Dimodifikasi Dan Kemampuan Memecahkan Masalah Terhadap Keterampilan Proses Sains Mahasiswa Pada Praktikum Fisiologi Tumbuhan, pancaran, (Vol. 4 No 3)

[4] Sirait, R., 2012, Pengaruh Model Pembelajaran Inquiry Training Terhadap Hasil Belajar Siswa Pada Materi Pokok Usaha Dan Energi Kelas Viii Mts N-3 Medan, jurnal Pendidikan Fisika p-ISSN 2252-732X e-ISSN2301-765, (VOL.1 NO.1)

[5] Anam, khoirul, 2017, Pemebelajaran Berbasis Inkuiri, Yogyakarta: pustaka pelajar

[6] Padmadewi, Ni Nyoman, dkk, 2013, Pengantar Micro Teaching, Depok: Raja Grafindo Persada

[7] Purwanto, Andik, 2012, Kemampuan Berpikir Logis Peserta Didik SMA Negeri 8 Kota Bengkulu Dengan Menerapkan Model Inquiry Terbimbing Dalam Pembelajaran Fisika, Jurnal Exacta, ISSN 1412-3617, (Vol.X. No 2)

[8] Farhan, Muhamad, dkk, 2014, Keefektifan PBL dan Inquiry Based Learning Ditinjau dari Prestasi Belajar, Kemampuan Presentasi Matematis, dan Motivasi Belajar, JurnalRiset Pendidikan Matematika, ISSN: 2337-9995. (Vol. 1, No.2)

[9] Hamzah. H. 2017. Pengaruh Model Pembelajaran Konstektual Melalui Metode Berbasis Penyelidikan Terhadap Hasil Belajar Peserta Didik Kelas X MAN 1 
Makassa. Jurnal Prosiding Kajian Ilmiah Dosen Sulbar, ISBN: 978-602-60838-1-4.

[10] Octaviany, Magdalena, 2014, Pengaruh Pembelajaran Model Problem Based Learning dan Inquiry Terhadap Prestasi Belajar Siswa Ditinjau dari Kreativitas Verbal Pada Materi Hukum Dasar Kimia Kelas X SMAN 1 Boyolali Tahun Pelajaran 2013/2014. Jurnal Pendidikan Kimia (Jpk), ISSN: 2337-9995, (Vol. 3 No. 4)

[11] Purwasih, ratni, 2015, Peningkatan Kemampuan Matematis Dan Self Confidence Siswa MTS Di Kota Cimahi Melalui Model Pembelajaran Inkuiri Terbimbing ISSN 1978-5089, (Vol, 9 No 1)

[12] Sayyadi, Muhammad, 2016, Pengaruh Strategi Pembelajaran Inquiry Terbimbing dan Terhadap Kemampuan Pemecahan Masalah Fisika pada Materi Suhu dan Kalor Dilihat Dari Kemampuan Awal Peserta didik, Jurnal Inpirasi Pendidikan Universitas Kanjuruhan Malang.

[13] Karli, H \& Yuliartianingsih, M.S, 2003, Implementasi Kurikulum Berbasis Kompetensi, Model-Model Pembelajaran, Bandung, Bina Media Informasi

[14] Nupita, evi, 2013, Penerapan Model Pembelajaran Penemuan Terbimbing Untuk Meningkatkan Hasil Belajar Dan Keterampilan Pemcahan Masalah IPA Pada Siswa Kelas V Sekolah Dasar, Jurnal Pendidikan Guru Sekolah Dasar (Volume 01 Nomor 02)

[15] Murni, Widya Arie, 2017, Pengaruh Penerapan Metode Inkuiri Terhadap Keterampilan Pemecahan Masalah Dan Penguasaan Konsep Pada Mata Pelajaran Ipa Kelas V Sdn Kemuning, Jurnal Ilmu Pendidikan (V01. 02 N0.7)
[16] Sudarma, Teguh Febri, 2016, Penerapan Model Pembelajaran Inquiry Training Just In Time Teaching (JIIT) untuk Meningkatkan Kemampun Pemecahan Masalah Fisika, Jurnal Ikatan Alumni Fisika Universitas Negeri Medan, P-ISSN 2461-1247, E-ISSN 2477-5142. (VOL.2 NO.1)

[17] Simatupang, Sehat, 2015, Pengaruh Model Pembelajaran Terhadap Hasil Belajar Siswa Pada Materi Okok Listrik Dinamis di Kelas X Semseter Ii Sma Negeri 8 Medan T.P 2013/2014, ISSN 2461-1247, (VOL.1 NO.1)

[18] Sugyono, 2016, Metode Penelitian Pendidikan Pendekatan Kuantitatif, Kualitatif, dan $R \& D$, Bandung: Alfabeta

[19] Susetyo, Budi, 2012, Statistika Untuk Analisis Data Penelitian, Bandung: Refika Aditama

[20] Siregar, Syofian, 2017, Statistik Parametrik untuk Penelitian Kuantitatif, Jakarta: Bumi Aksara

[21] Majid,A, 2016, Strategi Pembelajaran, Bandung: Pt Remaja Rosdakarya Ni

[22] Destalia, Lendy, dkk, 2014 Peningkatan Keterampilan Pemecahan Masalah Dan Hasil Belajar Melalui Penerapan Pembelajaran Berbasis Masalah (PBM) Dengan Metode Eksperimen Pada Materi Pencemaran Lingkungan, (Vol. 3, No. 4)

[23] Dewi, P.E, 2017, Efektivitas Modul Dengan Model Inkuiri Untuk Menumbuhkan Keterampilan Proses Sains Siswa Pada Materi Kalor, Jurnal Keguruan Dan Ilmu Tarbiyah, ISSN: 2579-7964 